\title{
Jozo Tomasevich: 1908-1994
}

Jozo Tomasevich, a leading expert on the economic and political history of former Yugoslavia, died on 15 October 1994 at the age of 86. Born in 1908 in Košarnido on the peninsula of Pelješac, Dalmatia, Professor Tomasevich completed his secondary education in Sarajevo, Bosnia, and his higher education at Basel University, Switzerland, where he earned a doctorate in economics. In the mid-1930s he worked as a financial expert at the Yugoslav National Bank at Belgrade. As a recipient of a Rockefeller fellowship, he came to the United States in 1938, availing himself of the rich resources of Harvard University. Before World War II he moved to California where he was a member of the scholarly staff of the Food Research Institute at Stanford University. During World War II he was affiliated successively with the Board of Economic Warfare and UNRRA in Washington, DC. After the war he was with the Federal Reserve Bank in San Francisco.

Preferring a professional assignment combining teaching and research, he joined San Francisco State College-now San Francisco State University-in 1948 and stayed there until his retirement in 1973 . In 1954 he taught at Columbia University for one year. Taking to heart the challenges of teaching, he gave his lectures rich and pertinent content, precise organization and warm delivery.

Tomasevich and Neda Brelić were married in 1937. Neda pursued her own professional career as a high school teacher. The partnership created ideal conditions for academic work and 57 years of family happiness. Surviving Jozo are his wife, Neda, three children (Anthony, Neda Ann and Lasta) and three grandchildren. In an essay published in 1976 in Communal Families in the Balkans: The Zadruga, edited by Robert F. Byrnes, Tomasevich offered an impressive sociological and historical analysis of his own extended family since the early nineteenth century.

From the time he had reached the age of 25 , until his death, Tomasevich was involved in an uninterrupted succession of research projects, some of epic proportions. Guided by a temperament that encouraged inner discipline, he gave undivided attention to each of the research projects until full completion had been achieved. This habit helped give his studies impressive depth and breadth.

The evolution of Tomasevich's scholarship passed through three distinct phases. In the 1930s (actually from 1934 to 1938), he published three books. Die Staatsschulden Jugoslaviens and Financijska politika Jugoslavije provided a solid and much cited analysis of government efforts to stabilize national finances at the outset of the great depression. Novac $i$ kredit, a general treatise, helped train an entire generation of Yugoslav financial experts. The second phase covered the 1940s and 1950s and is dominated by two studies of large proportions. International Agreements on Preservation of Marine Resources (1949) presents a highly competent inquiry into international relations in the Pacific basin centered on an issue of vital economic importance. Peasants, Politics, and Economic Change in Yugoslavia (1955), a study of monumental scope, has been widely recognized as the most comprehensive and accomplished study in the field. The book supplies cogent information on the historical roots of each national group encompassed by former Yugoslavia. The study is impressive testimony to Tomasevich's ability both to penetrate the depths of messages carried by documentary material and to be scrupulously careful in drawing conclusions. In this book, Tomasevich was eminently successful in placing the economic problems of the Yugoslav peasantry within a larger social, political and historical framework.

The third phase began in the late 1950s when Tomasevich undertook to write a trilogy on the historical events in Yugoslavia during World War II. The first part of the trilogy-The Chetniks-appeared in 1975. The manuscript of the second volume, which treats the quisling governments in former Yugoslavia, is ready for submission to a publisher; 75 percent of the third volume dealing with the partisans has been completed. A volume of more than 700 pages, The Chetniks is basically a study in politics, ideology and military operations, although the role of the economic factor has not been overlooked. It is clearly the most exhaustive study so far of the military

Slavic Review 54, no. 1 (Spring 1995) 
forces in Yugoslavia dedicated to the restoration of the Serbian monarchy after the end of World War II. The book casts significant light on the multiple facets of the conflict between the Chetniks and the partisans. It has been translated into Serbo. Croatian.

Among many honors, Tomasevich was the recipient of the Award for Distinguished Contributions to Slavic Studies from the American Association for the Advancement of Slavic Studies in 1989. He was a master of scholarly skills, a person with bountiful erudition, wit and human dignity.

AltiXander Vuginich

Berkeley, CA

January 1995

\section{Barbara Jelavich: 1923-1995}

Barbara Jelavich, Distinguished Professor of History emeritus at Indiana University and honorary member of the Romanian Academy, passed away in Bloomington, Indiana, on 14 January 1995, after a long and courageous battle with cancer. Her life and work as scholar, teacher, mentor, colleague and friend greatly enriched Habsburg, Russian, Ottoman and southeast European studies. Her death diminishes us, but her contributions will inform, guide and inspire for a long time to come.

Born 12 April 1923, Barbara Brightfield earned successive degrees in history from the University of California at Berkeley (an A.B. honors degree in 1943, an M.A. in 1944, and a Ph.D. in 1948). In 1944, she married Charles Jelavich, beginning a deep and exemplary personal and professional partnership that spanned six decades, produced dozens of important studies, and taught two new generations of scholars. Their collaboration was appropriately recognized in 1992 when they were jointly honored with the AAASS Award for Distinguished Contributions to Slavic Studies. (This double distinction is, to date, sui generis.) Perhaps even more significant testimony to their work has been provided by the hundreds of letters her husband has received since Barbara's death from students, peers, and others whose lives and minds were touched and shaped by the Jelaviches.

Barbara Jelavich taught briefly at Berkeley and Mills College, and then devoted her time to raising the Jelaviches' two sons, Mark and Peter, while conducting further research in diplomatic and Balkan history. In 1961, she and her husband came to the Department of History at Indiana University. There, she was promoted to professor in the Department of History in 1967, and named Distinguished Professor of History in 1984. She served as chairman of the Conference on Slavic and East European History (1979) and President of the Society for Romanian Studies (1988-1990). In 1992, when the Jelaviches retired, she was elected an honorary member of the Romanian Academy. That same year, she was given the first Lifetime Achievement Award by the Association for Women in Slavic Studies. Her tireless and conscientious efforts on committees and scholarship bodies on behalf of the profession and the field should also be noted. In 1992, a well deserved festschrift (including their extensive bibliography) was published for Barbara and Charles Jelavich under the editorship of Richard Frucht.

Few people have been so well qualified professionally and personally to work in the unique historical laboratory that is eastern Europe, or have made such significant efforts toward helping the region find its larger place in the world of historical scholarship than Barbara and Charles Jelavich. Working as a team, through travel, research and persistent scholarly effort, they developed a profound, intimate, and empathetic acquaintance not only with the histories, lives, and cultures of the principal Balkan countries (Romania, Bulgaria, Yugoslavia, and Greece), but also with the empires which so deeply influenced their histories (Russian, Austrian, and Ottoman).

Among Barbara Jelavich's many achievements one surely stands out: her ability to make learned scholarship clear and intelligible without sacrificing accuracy or patronizing her audience. Her lectures were graceful models of the true teacher's art, capable of holding the attention of the least committed student and unerringly leading her audience through the most complex thickets of diplomatic contrivance. (I suspect 